\title{
Developing a Model of Recognition of Work Experience and Learning Outcomes Based on Indonesian National Qualifications Framework for Vocational High Schools Students
}

\author{
Zamtinah, Soenarto, Djemari Mardapi \\ Universitas Negeri Yogyakarta \\ Yogyakarta, Indonesia \\ E-mail: zamtinah@uny.ac.id
}

\begin{abstract}
This study aimed to develop a Model of Recognition of Work Experience and Learning Outcomes (ReWELO) Model and a guidebook for the ReWELO implementation. The method to develop the ReWELO model was research and development adapted from Borg \& Gall. The ReWELO model implementation was evaluated through competency and portfolio assessments. The subjects for the competency assessment were 18 students from 18 public and private Vocational High Schools running the Electrical Engineering Expertise Field in the Special Region of Yogyakarta while the subjects of portfolio assessment were 13 people from the informal sector, civil servants, industry, BATAN, PT KAI Yogyakarta, POLDA DIY, and AAU DIY. The instruments of the study consisted of questionnaires and observation sheets. The instruments' validity and reliability were assessed through expert judgment and Cronbach's Alpha respectively. The collected data were then analyzed descriptively. The results of the study were as follows: (1) The ReWELO model could be implemented through 2 methods, namely competency and portfolio assessments. (2) The developed ReWELO Model was categorized as very good to be applied with an appropriateness score of 3.67. (3) The $t$ aspects of portfolio components and language were categorized as valid with validity value of 3.69 and a very valid with the validity value of 3.71 respectively.
\end{abstract}

Keywords--ReWELO, INQF, Electrical Engineering, portfolio assessments

\section{INTRODUCTION}

One of the impacts of globalization is a country cannot implement protective regulations on the labour movement from abroad to the country or vice versa thus, to deal with employment issues caused by unrecognized competency, a mechanism of recognition of prior learning (RPL) and recognition of current competency should be formulated. Therefore, it is common that the recognition of work experience and learning outcomes of a person becomes a crucial issue in the global employment. There are several terms used in connection with RPL. In Malaysia, RPL is called Accreditation of Prior Experiential Learning (APEL). In the United States, RPL is known as Prior Learning Assessment (PLA). In England, Scotland and Ireland, RPL is called as Accreditation of Prior Learning (APL), in Canada it is used the terminology of Prior Learning Assessment and Recognition (PLAR), and in Indonesia RPL is termed as Recognition of Work Experience and Learning Outcomes (ReWELO) or in Indonesian called Pengakuan Pengalaman Kerja dan Hasil Belajar (PPKHB). ReWELO is a process of recognition of work experience and learning outcomes of a person either gained through experiences in the workplaces, formal, informal and non-formal education, which can be used to obtain equality of formal education. In other words, work experiences and learning outcomes can be obtained by self-taught and non-selftaught learning.

As a part of the international community, Indonesia has also ratified several conventions associated with RPL namely the General Agreement on Trade and Services (GATS) on 5 April 1994, the World Trade Organization (WTO) on January 1, 1995, Asean Free Trade Area (AFTA) in 1992, and The Recognition of Studies, Diplomas and Degrees in Higher Education in Asia and the Pacific on January 30, 2008. Indonesia also becomes a member of the Asia Pacific Economic Community (APEC) which states the liberalization of trade and investment in 2010 for developed countries and 2020 for developing countries. In addition, Indonesia also ratified the Asian Free Labor Agreement (AFLA) and AEC ASEAN Economic Community (AEC) which provide opportunities for exchange of workers among the members. Ratifications of those various regional and international conventions and the existence of foreign workers in Indonesia, significantly place Indonesia as a country which is more open and easily infiltrated in many sectors including labour or human resources. It also slowly yet surely shifts the protective regulations for Indonesian workers. That means Indonesia is not able to prevent foreign workers to work in Indonesia thus Indonesian local workers otherwise are unable to work abroad or even in the country if they are not equipped with competence and qualifications required by the labour market. A labour can no longer rely solely on a diploma certificate. Therefore, in order that Indonesian human resources survive and keep moving forward in the global economic arena, mutual and equal recognition of qualifications and learning outcomes owned by Indonesian workers need to be formulated and be protected with legal and credible recognition. 
Globalization also leads to a domino effect, namely in the field of the industry it will bring a variety of industries, such as a sunset industry, sunrise industry, multinational corporation (MNC) or transnational corporation (TNC). The emergence of new industries will affect the changes in the structure of labour in Indonesia in terms of quantity, type, and qualification, which in turn impacts on increasing competition for the job market. The questions are as follows: Are the Indonesian workers ready with these changes? Are they able to compete with foreign workers who enter Indonesia? Do Indonesian workers who work abroad have been equipped with the required competencies? Have the competences of the Indonesian workers received international recognition? Does Indonesia have regulations and legal aspects to protect migrant workers to ensure their dignity and self-esteem as Indonesian?

In the field of formal education, increasing mobility and recognition of qualifications of diploma holders who will work or continue their education abroad, as well as the exchange of experts and students across the country, are increasingly demanding Indonesia be better prepared to implement the policy of ReWELO. Similarly, the increasing flow of global information generated by the development of ICT also has an impact on the ease of access to information and labour recruitment through online facilities. Therefore it is not negotiable for immediate development of the model of competency recognition using online information technology because the penetration of foreign workers to Indonesia will be more difficult to be controlled. Great expectations for workers to get recognition for competencies achieved through learning outcomes and work experiences are concentrated on government policy in implementing the Indonesian National Qualifications Framework or Kerangka Kualifikasi Nasional Indonesia (KKNI), especially the ability of KKNI to be the interface of the needs of Indonesia workers' competency recognition. Therefore, as the policy of KKNI is proceed, it needs to be translated into a more operational description of qualifications in various fields including the field of Electrical Engineering. However, the implementation PPKHB or ReWELO in Indonesia deals with problems, uncertainty, and unpreparedness. The competence of a person has not received appropriate recognition and appreciation. People still appreciate a diploma certificate rather than work experiences over the years.

The aims of this study were to develop a model of the recognition of work experience and learning outcomes or ReWELO through the review of experiences of various countries that have already applying RPL yet adapted to the situation in Indonesia. The novelty value of this study is the mechanism of the implementation can be done manually or online by utilizing information and communication technology. In addition, the use of KKNI as the basis is also a novelty because the existing competency models for vocational high schools of Electrical Mechanical that is not based on KKNI. Several theories were studied to develop the model of ReWELO that consisted of lifelong education, implementation of ReWELO, KKNI, ReWELO assessment methods, and competence of the field of Electrical Engineering which is equivalent to vocational school graduates or KKNI Level 2.
Lifelong education is closely associated with vocational education. Lifelong education defined by Miller (1986) as one of the principles of vocational education. Lifelong education can promote vocational education. Djojonegoro (1998) even states that lifelong education is able to solve problems of vocational graduates relating to career stagnation known as "dead end". Lifelong education has also become one of the organizing principles of education in Indonesia as stated in Law No. 20 The year 2003 on National Education System Chapter III, article 4, paragraph (3) which states that education is organized as a process of acculturation and the empowerment of learners that lasts a lifetime. Lifelong learning is a concept, an idea, main idea, a belief that animate, underlie and provide the identity of a system (Haryono, 1995). This concept is embodied in the belief that learning does not only take place in formal educational institutions. Someone can gain knowledge if he want after he finished his education in a formal educational institution. It also stressed that learning in a real sense is something that lasts throughout a person's life. The idea states that the concept of lifelong learning is sometimes said to be a continuous learning (continuing learning). By constantly learning, a person will not be outdated and may renew their knowledge and competence. With the knowledge that is always updated, a person will not be alienated, will not be still or early dementia, and can still contribute to life in their neighbourhood.

The characteristics of people who become lifelong learners (Cropley, 1977) are: (1) Realizing that they have to do lifelong learning; (2) they have the view that learning new things is a logical way to solve the problem; (3) high Eager to learn at all levels; (4) welcoming changes.; and (5) Believing that the challenge throughout life is an opportunity to learn new things. In connection with the reasons for the importance of lifelong education, Cropley (1977) gives a number of reasons, namely: (1) justice; (2) the economy; (3) social factors; (4) the development of science and technology; and (5) the nature of the work.

From the five reasons, the reason which attracts the concern is economic reasons and nature of work. Undeniably, the economic rationale is the vital reason in providing education. Especially in developing countries, the costs for the expansion of education and improving the quality of education is hardly insurmountable. There are challenges to overcome delays in development, while on the other hand there is a barrier related to funding. Relating to the nature of work, the reality shows that the development of science and technology in a large scale confiscates handwork which is replaced by machines, but on the other hand it also contributes to the emergence of the new jobs that absorb a lot of labor and the emergence of new ways of processing works, As a result, the job requirements are always changing.

Based on those characteristics and reasons, the principle of lifelong education is appropriate for people who live in the world of transformation and in the community who's the members affect each other like in this era of globalization. Philosophy, Essentialism, pragmatism and existentialism embraced by vocational education in Indonesia, require every person engaged in vocational education to constantly adjust their selves to new situations, new science, and new 
technology. It is intended to guarantee and maintain the existence and the dignity of vocational education practitioners in life and living, as shown in Figure 1.

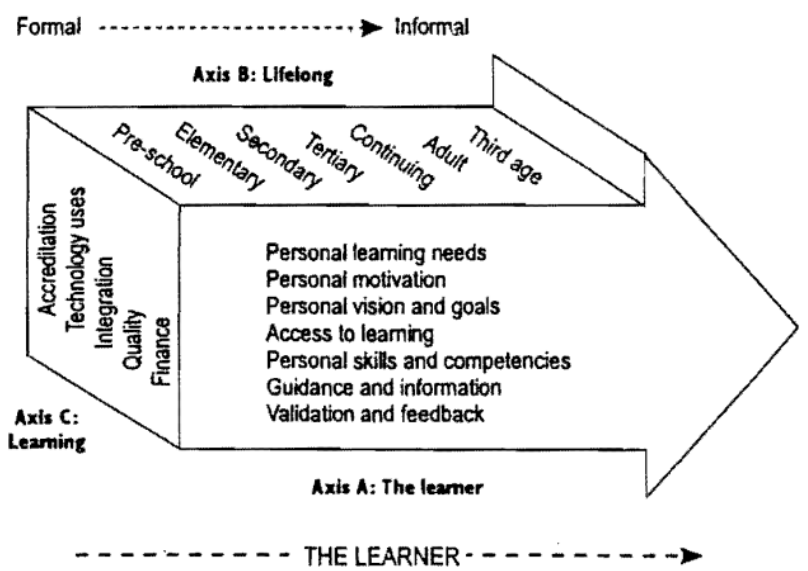

Fig. 1. Lifelong learning process (Source: Longworth, 2003)

Figure 1 shows that lifelong education becomes a higher sense of urgency at the moment because humans need to adapt in order to survive naturally in a continuing changing community. The Broad Outlines of the Nations of Indonesia states that education lasts a lifetime and is implemented within the household, school and community. Therefore, education is a shared responsibility between families, communities and the government. This means that every person in Indonesia is required to always evolve throughout his life. Therefore, the public and the government should create an atmosphere or a climate of good learning, because formal education is not the only place to learn, but there is a system of non-formal and informal education that contribute to the implementation of lifelong education.

ReWELO stands for Recognition of Work Experience and Learning Outcomes that in terms of Indonesia called Pengakuan Pengalaman Kerja dan Hasil Belajar (PPKHB) (Director General of Quality Improvement of Teachers and Education Personnel, Ministry of National Education, 2010). PPKHB which was later translated into English as ReWELO, originally used by the Director General of the Indonesian Ministry of National Education to fulfil the mandate of the law of Teachers and Lecturers to help teachers without the qualification of bachelor degree through a program called PPKHB. In this study, ReWELO is defined as an assessment method for someone who wants to gain recognition for knowledge, understanding, skills and competencies acquired either through formal, non-formal and informal education, both self-taught and non-self-taught learning. This definition suggests that the results of lifelong learning through formal education, non-formal, informal, or work experience can be recognized through the establishment or the equalization of appropriate levels that exist in KKNI and is strengthened as the law through the National Education Law, the Regulation of the Minister and another policy. The learning results or outcomes are usually in the form of a score value that describes the achievement of a learning process that has been done (Lestari \& Siswanto, 2015, p.187).
As described in the previous section that the implementation ReWELO in Indonesia has not been explicitly institutionalized or if it existed it used different terminology such as credit transfer, bridging or bridging training course. However, the implementation of the program depends on the era of government policy. For example, the bridging program course/training coined in the era of 1994 when the Ministry of Education and Culture chaired by Wardiman Djojonegoro. When there is a change of government, the policy is not heard anymore.

The model developed in this study refers to the implementation of existing competence certification and also reviews the implementation of ReWELO in some countries, shown in Figure 2. Some of the institutions involved in the implementation process of ReWELO are as follows: Standard of competence by considering the needs of industry, government agencies, as well as the other employment needs which were determined by the National Professional Certification Board (BNSP), National Education Standards Agency (BSNP), industries, professional Certification Institute (LSP), professional associations such as the Indonesian Engineers association (PII), the Indonesian Doctors Association (IDI ), as well as other stakeholders. Several government agencies such as the ministry of education, the ministry of industry, labour ministry are involved in the process PHBA, as well as the issuance of the certificate. The successful implementation of ReWELO can be viewed from the aspect or ReWELO scoring system and how it can be implemented properly. In more details in the implementation ReWELO when it is viewed from the aspect of the assessment the factors that can be observed including accountability, the simplicity of the assessment method, objectivity, transparency, accountability, and involvement of participants in the assessment. In connection with the implementation of the model, Nitko \& Brookhart (Djoko Laras, 2013 p.105) states that it should pay attention to four things: finance, efficiency, practicality, and the possibility of modification. In this study, the factors to be observed with regard to the implementation of the Model ReWELO are: practicality, simplicity, clarity stages of implementation, cost savings, fewer tools and materials, time, implementers, and can potentially be carried out online.

The study of ReWELO implementation in some countries in principle is not much different from the implementation of RPL. Some of the weaknesses that can be encountered include: subjectivity is still possible for example in the implementation of vocational competency test, the assessors involved are usually the teachers from the vocational school being assessed thus there may be some subjectivity of the assessment. Another weakness are that not all students participate in the competency test or competency test participants are only representatives of a student whose achievement is more prominent than others. If the results of competency tests revealed into a good category by the assessors from outside the school, it is not fair since the results are not the representations of all students. If it is viewed from the candidate or the participant of the competency test, the previous implementation has not yet accommodated candidates from non-formal, informal, or individual, meaning that the participants still came from formal educational institutions. 
Based on the existing implementation of the competency test, this study is intended to improve the existing models. The ReWELO model developed in this study will accommodate not only the candidates from formal educational institutions, but also the candidates who obtain competency form autodidact learning, non-formal and informal educational institution, or through work experience and training. Another improvement is the use of information and communication technology, so it can be implemented on-line so that candidates who are located far will not have to leave his job. Another benefit is the model of on-line ReWELO ensure neutrality, objectivity and transparency of the assessment. This developed model is also based on KKNI. This is consistent with the principles issued by the Ministry of Education that the assessment of work experience and learning outcomes adhere to the principle of relevance, professional, originality, objectivity, transparency, accountability, and systematic (Dijen PMPTK 2010 p.p. 5-6).

KKNI is prepared based on the needs and specific objectives, which is typical for Indonesia to align education and training systems with a career in the world of work. KKNI is also designed to conform and on par with the developed system of other countries. In its development, KKNI also refers and consider the qualifications systems of other countries such as Europe, Australia, England, Scotland, Hong Kong and New Zealand. It makes qualifications included in KKNI can be compared and accepted by other countries so that the exchange of students and labour between countries can be conducted properly. KKNI development has general and special goals. The general goals include things that can encourage integration between different sectors, while the specific goals include the strategic aspects of the development of the framework and the qualification levels. General goals of KKNI are: 1) Increasing the commitment of governments and communities to produce high quality and competitive Indonesian human resource; 2) To encourage the improvement of quality and accessibility of Indonesian human resources to national and international labor market; 3) Build an accountable and transparent recognition process on the outcomes of learning acquired through formal and non-formal education, informal, training or work experience recognized by the world of work nationally and/or internationally; 4) Increase the contribution of learning outcomes acquired through formal education, non-formal, informal, training or work experience in national economic growth; 5) Encourage the transfer of learners, students, and labor between countries based on equality of qualifications. (Indonesian Qualification Framework 2010 pp.8-9)

While the Special goals of KKNI are: 1) Obtaining a positive correlation between the quality of outputs, outcomes and processes of learning in higher education; 2) Encourage learning outcomes adjustment and equalization of the quality of higher education graduates at the same level of qualification; 3 ) Being a principal guidelines for universities in developing mechanisms of recognition of learning outcomes in the past (recognition of prior learning) or the experience of a person; 4) Being a bridge of mutual understanding between college and graduate users to sustainably build capacity and competitiveness nation, especially in the sector of human resources; 5) Giving the guideline for the graduate users to make qualification and ability adjustments to develop programs for lifelong learning (lifelong learning programs); 6) Ensure the increased accessibility of human resources in Indonesia to national and international labor market; 7) Obtain recognition of other countries bilaterally, regionally and internationally without leaving the traits and personality of Indonesia; 8) Facilitate the development of academic mobility mechanisms to increase mutual understanding and solidarity and cooperation between countries in the higher education world (Indonesian Qualification Framework 2010 pp.8-9)

The general description of KKNI is as follows: 1) Devoted to God Almighty; 2) Having a moral, ethical and good personality in completing the tasks; 3) Serve as a citizen who proud and love of the homeland and supporting the world peace; 4) Having the ability to work together and have a social sensitivity and concern towards society and the environment; 5) Respect for cultural diversity, views, beliefs, and religion and opinion / original findings of others; and 6) Uphold the rule of law and have the spirit to put the interests of the nation and the wider community. The specific description of KKNI level 2 is: Able to perform a specific task, using the tools and information, and work procedures commonly performed, as well as performing with measurable quality, under the direct supervision of the superiors; Having a basic operational knowledge and factual knowledge of specific areas of work, so that they can choose the solution that is provided to the common problems that arise; and Responsible for own work and can be given the responsibility of guiding others.

Some countries that have implemented RPL use some kind of assessment techniques to carry out a credit transfer towards one's work experiences and learning outcomes. According to Kaprawi (2011), the types of assessment are portfolios, interviews, text and examination, presentation, demonstration, and site visit. Furthermore, Wellington et.al., (2002:170) found some authentic assessments that can be used such as assessment of performance, assessment based on criteria, systematic observation by instructors or learners, portfolios, and journals. Meanwhile, Bott (1996:187-191) states that in addition to written tests, tests and assessments for occupational and technical education can implement non-test methods. The methods are homework, case studies and problem-solving assignments, projects, observations, portfolios, affective behavioural assessment.

The assessment methods used in this research study were portfolio and competency test (performance assessment) with undertaking some considerations that almost all countries that implement RPL use the portfolio as one of the assessment methods. According to Bott (1996:190), the portfolio is a collection of some of the projects engaging learners in a significant period of time and producing products. The portfolio is also the best work that has been done by learners. According to Mardapi (2000:2), performance assessment is an assessment of the acquisition process, application of knowledge and skills through a learning process that demonstrates learners' abilities in both process and product. One assessment that is widely used in determining one's ability is performance assessment since it is considered more authentic and reflects the true ability of the learners. Electricity power system starting from generations to consumers is a very complex system incorporated by a system of generation, 
transmission, distribution, and utilization which require human resources with diverse competencies from its types and its levels of competence. In relation to this the Ministry of Energy and Mineral Resources through National Working Competency Standard of Indonesia (SKKNI) divides the electrical competency into the following categories: Conventional Electricity Generation Competencies, New and Renewable Energy Generation Competencies, Electric Power Transmission Competencies, Electric Power Distribution Competencies, Electrical Installation Competencies, Industrial Electricity Utilization Competencies, and Industrial Equipment Competencies.

Conventional Electricity Generation Competencies consist of competency standards of operator, maintenance, inspection, construction, Hydro Power Plant (PLTA) operations planning, Hydropower Plant maintenance planning. The standards of competency for New and Renewable Energy (ETB), maintenance, inspections such as Wind Turbine Power Plant (PLTB), Biomass Power Plant (PLTBM), Micro Hydro Power Plant (PLTMH), and Solar Power Plant (PLTS) are: EBT generation Operations-Maintenance-Inspection-Construction for PLTB, PLTBM, PLTMH and PLTS. Competencies in the field of Electric Power Transmission include competency planning, inspection, operation, and maintenance of transmission. As for the competencies in the field of Electric Power Distribution, they are similar to the ones in Transmission. The difference only lies in the term of transmission which is replaced with distribution. Competencies for Industrial Electricity Utilization include standards of competence of Industrial Electricity Utilization in the manufacture, support, maintenance, coordination, and quality design control. Meanwhile, competencies for Industrial Equipment include electric power equipment industry in the fields of planning, control and quality assurance, maintenance and machine reparation, manufacture, and support. Competencies in electrical fields as described above, in the world of education it is expressed with a term expertise package. As for the electricity sector, expertise package consists of two namely Mechanical Electricity Package consisting of Power Plant Engineering, Installation of Electricity Utilization, Industrial Automation, and Cooling and Air Conditioning Engineering. While the Expertise Package of Renewable Energy consists of Hydro Energy Engineering, Solar and Wind Energy Engineering and Biomass Energy Engineering. (Lampiran SK Dirjen Mandikdasmen tentang Spektrum Pendidikan Menengah Kejuruan 2008).

Based on the explanation above, the standard of competence contained in SKKNI, in point of fact, had been included in Vocational School (SMK) spectrum. However, since these competencies set to the level of Vocational School (SMK) it was then adjusted to the level of extension and depth of the material competences. Being associated with the KKNI it was equivalent to level 2. In connection with the job description of electrification that can be held by the technician equivalent to vocational school graduates according to SKKNI is planning sector, operation sector, inspection sector, operation and maintenance sector.

\section{RESEARCH METHODS}

\section{Research Location}

Data on ReWELO development system accessed online are laboratory-scale data, conducted at the Data Communication Laboratory of Department of Electrical Engineering Education, Faculty of Engineering UNY. This laboratory has wide varieties of application programs and latest hardware and is connected to the Internet by LAN system so that it can be utilized to create ReWELO program online. Data in relation to the determination of KKNI descriptors level 2 were taken from respondents which are located both in and outside Yogyakarta Special Regency (PT. LEN Bandung, PT. Smart Energy Universe Cikarang, PT. Schneider Electric Indonesia Cikarang, PT. Bukaka Teknik Utama Bogor, PT. PLN Persero, and LSP Gema PDKB Semarang).

\section{Type and Instrument Research}

This type of research is R \& D model by Borg and Gall with various modifications. The instruments used were video and library documents. Validity and reliability of the instrument are shown in Table 1.

TABLE 1. VALIDITY AND RELIABILITY OF THE INSTRUMENT

\begin{tabular}{|l|c|l|}
\hline \multicolumn{1}{|c|}{ Instrument } & Validity & \multicolumn{1}{|c|}{ Reliability } \\
\hline Questionaire & Very valid & $\begin{array}{l}\text { Cronbach's Alpha } \\
\mathrm{r}=0,844\end{array}$ \\
\hline $\begin{array}{l}\text { ReWELO } \\
\text { Implementation }\end{array}$ & Valid & $\begin{array}{l}\text { Cronbach's Alpha } \\
\mathrm{r}=0,968\end{array}$ \\
\hline $\begin{array}{l}\text { Achievement of competence } \\
\text { test }\end{array}$ & Valid & $\begin{array}{l}\text { Cronbach's Alpha } \\
\mathrm{r}=0,978\end{array}$ \\
\hline $\begin{array}{l}\text { Achievement of portfolio } \\
\text { assesment }\end{array}$ & Valid & $\begin{array}{l}\text { Cronbach's Alpha } \\
\mathrm{r}=0,977\end{array}$ \\
\hline
\end{tabular}

\section{Trial Subjects of ReWELO Model}

Trial subjects for the implementation of ReWELO were carried out through competency test consisting of four elements, namely candidates or students, assessors, technicians or lab-techs from workshop or laboratory where the competency test was held, and also the students of Electrical Engineering Education Department who belonged to the members of Electrical Installation Development Team. The assessors consisted of three people from LSP Gema PDKB, from college, and from Electrical Engineering instructor at Technical Education Training Center (BLPT) Yogyakarta. Electrical Installation Development Team delegated 5 students in charges of preparing equipment, testing materials and equipment used for a competency test, to make sure whether it met the standards or not.

Furthermore, subjects of the trial especially from the candidate or students were 18 people coming from public and private vocational schools in Yogyakarta who had electrical expertise. Trial subjects of ReWELO Model through portfolio assessment consisted of 2 assessors and 13 candidates from diverse government agencies (PNS), BUMN, TNI/POLRI, industry, and non-formal workers at the electric field. The respondents in this study came from various institutions, e.g. academicians and vocational school teachers, practitioners, industries, professional associations, as well as experts in electrical engineering, which consisted of 18 people. 


\section{Data analysis}

Data analysis techniques used in this study were adapted to the types of data and types of products, namely: Data on the development of ReWELO Model were analyzed descriptively; data on the ReWELO achievement through competence tests were analyzed descriptively. Candidates who obtain a score of 70 and up were declared Competent and awarded a certificate of competency. While data on the ReWELO achievement through portfolio assessment were analyzed descriptively. The total scores of the portfolio obtained by the candidates, later on, were equalized in the form of acquisition of semester credit units (credit transfer).

\section{RESULTS AND DISCUSSION}

Some matters becoming the objective assessment of the respondents in the development of ReWELO Model were the effectiveness of the model in terms of ease of the model workflow to understand, ease of the recognition process to implement, and simplicity of the implementation mechanism of ReWELO Model. The responses toward ReWELO Model were expressed in the form of scores that be seen completely in Table 2.

TABLE 2. ASSESSMENT OF DEVELOPMENT ASPECTS OF REWELO MODEL

\begin{tabular}{|c|c|c|}
\hline \multirow{2}{*}{ Aspect } & \multicolumn{2}{|c|}{ Score } \\
\hline & Mean & Total Mean \\
\hline Ease of model workflow to understand & 3,67 & \\
\hline $\begin{array}{l}\text { Ease of recognition process } \\
\text { implementation }\end{array}$ & 3,60 & $\begin{array}{c}3,67 \\
\text { (Category: }\end{array}$ \\
\hline $\begin{array}{lll}\begin{array}{l}\text { Simplicity } \\
\text { mechanism }\end{array} & \text { of implementation } \\
\end{array}$ & 3,73 & Very Good) \\
\hline
\end{tabular}

\section{Guide Book Validity}

There are two types of guidebook concerning to the methods to implement ReWELO Model, namely ReWELO Implementation Guide through Portfolio Assessment and ReWELO Implementation Guide through Competency Test. ReWELO Implementation Guide is one of this research product which is expected to be able to guide the implementation of ReWELO Model. The guidebook should be comprehensible for users, and therefore it needs to pass feasibility test before being published. Some parties involved in the validity of guidebook assessment were 12 people consisting of academicians, experts in technology and vocational education, vocational school teachers, assessors, Regional Office of Social Manpower and Transmigration (Depsnakertrans) Yogyakarta, professional associations, as well as from industries. The validity of ReWELO Implementation Guide Book was reviewed from two aspects, namely portfolio components and language aspect. Table 3 shows the feasibility assessment by the respondents in FGD.

Some inputs related to the guidebook improvement are 1) the conceptual model should be completed with the studies of work attitudes, SKKNI; 2) the hypothetic model images should be completed with instrumental and outcome components; 3 ) the level of KKNI should be focused on level 2 only; 4) the abbreviations used should have the explanation what they stood for; 5) the certification on the input component should be replaced with the assessors.

TABLE 3. AsSESSMENT OF REWELO MODEL GuIDE VALIDITY

\begin{tabular}{|c|c|c|}
\hline \multirow{2}{*}{ ASPECT } & \multicolumn{2}{|c|}{ SCORE } \\
\hline & AVERAGE & AVERAGE/ASPECT \\
\hline \multicolumn{3}{|c|}{ The components of ReWELO Model Guide } \\
\hline Comprehensive & 3,73 & \multirow{5}{*}{$\begin{array}{c}3,69 \\
\text { (Very Valid) }\end{array}$} \\
\hline Representative & 3,87 & \\
\hline Proper & 3,47 & \\
\hline Accuracy of references & 3,67 & \\
\hline Accuration of scoring & 3,73 & \\
\hline \multicolumn{3}{|l|}{ Language } \\
\hline Simple & 3,67 & \multirow{3}{*}{$\begin{array}{c}3,71 \\
\text { (Very Valid) }\end{array}$} \\
\hline Communicative & 3,73 & \\
\hline $\begin{array}{l}\text { Appropriate } \\
\text { Indonesian } \\
\text { Rules }\end{array}$ & 3,73 & \\
\hline
\end{tabular}

\section{The implementation of ReWELO Model}

ReWELO model execution was undertaken through two methods of assessment that were competency test and portfolio assessment either off-line or online. The investigated or observed aspects which were associated to the enforceability of ReWELO were assessment system aspect and implementation aspect. Both of these aspects were considered good. Observer involved observing the implementation of ReWELO amounted to 6 people, consisting of four assessors and two technicians who assisted the implementation of the competency test and the tabulation of the test results from the very beginning to the very end of the execution.

\section{Results achieved from the Implementation of ReWELO Model}

The competency test score is a combination of psychomotor score, affective score, and cognitive score. The weight of each score is different but adapted to the level of difficulty, time of execution, and question complexity. The formula to determine the competency test is as follows:

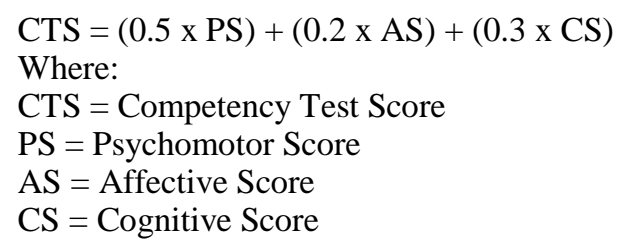

Candidates who achieved a score of 70 and up were declared Competent (K), while the ones with competency test score below 70 were declared Not Yet Competent (BK). Based on the calculation of competence test above it was obtained that from 18 candidates, $12(67 \%)$ of them achieved scores above 70 , then were declared COMPETENT (K) and deserved a certificate of competency from LSP PDKB Region IX Yogyakarta Special Regency. While the candidates who gained 
the competence test value below 70 there were 6 candidates (33\%) so that were stated NOT YET COMPETENT (BK) and not awarded with the certificate. Figure 2 illustrates the percentage of achievement of the results of competency tests.

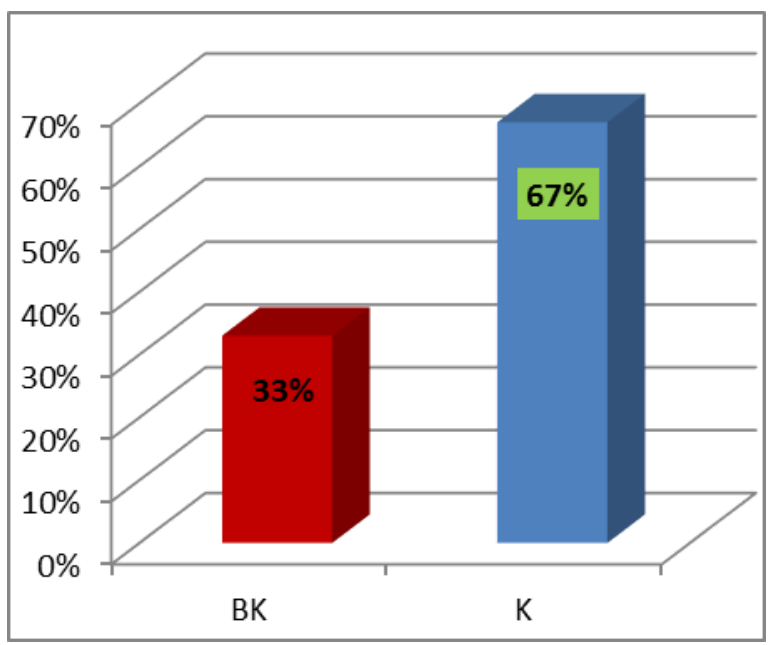

Figure 2. Percentages of competency test results.

Acknowledgement of work experiences and learning outcomes awarded to candidates through portfolio assessment differs from that produced from a competency test. Incompetency test, direct performance of the candidates is assessed; while in portfolio assessment, it is the photocopies of physical evidence, work experiences and learning outcomes owned by candidates, which are assessed. The acknowledgement to the portfolios recognized by candidates is in the form of scores which is then converted into credits (SKS) as presented in Figure 3.

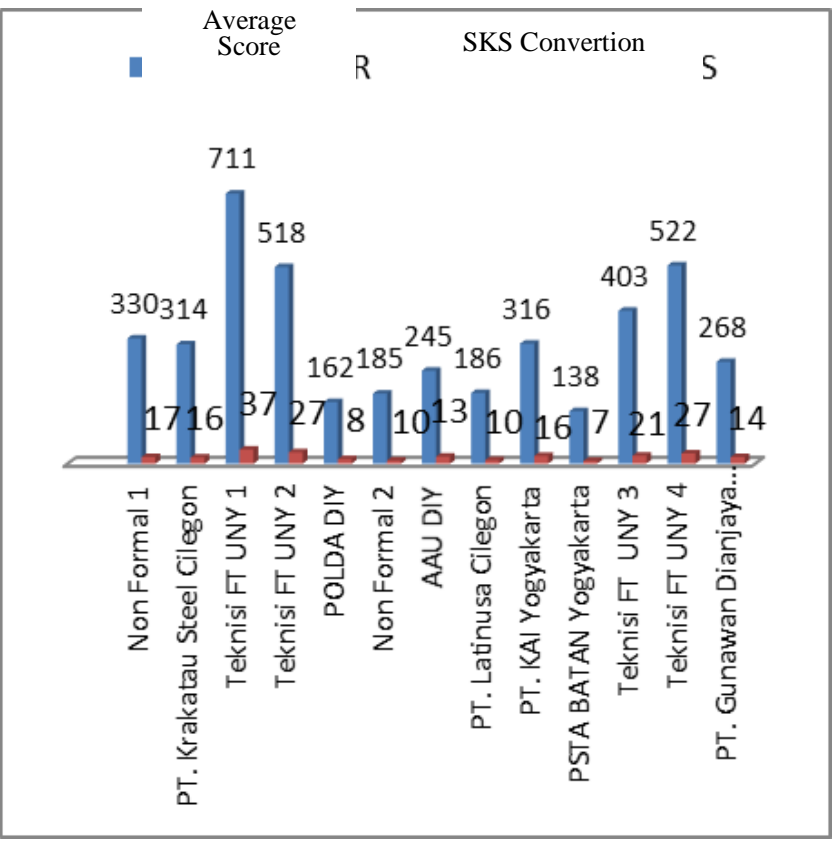

Figure 3. Results of a credit transfer achieved by candidates through portfolio assessment
Figure 3 shows the results achieved by candidates who recognize their work experiences and learning outcomes through portfolio assessment.

\section{CONCLUSIONS}

ReWELO Model is developed through Recognition of Prior Learning (RPL) implementation studies in some countries and is consulted with experts through FGD. Later on, the rectified result in accordance with the experts' suggestions is then tested. Based on these studies, the relevant model is set in accordance with the conditions in Indonesia. ReWELO Model can be implemented in Indonesia through two methods, namely Competency Test and Portfolio Assessment, both off-line and online. The ReWELO model developed in this study tended to be rated as "Very Good". Based on the validity criteria as the reference to the study "The Guidebook of ReWELO Model Implementation" belonged to the category "Very Valid".

\section{SUGGESTIONS}

To make benefits of the products of this research it requires understanding and specific skills. Therefore, readers or practitioners need to consider the following suggestions: 1) ReWELO Model can be implemented through competency test and portfolio assessment. To implement the competency test it is suggested that the interested parties need to understand The Guidebook of ReWELO Model Implementation through Competence Test; 2) For candidates who recognized work experiences and learning outcomes through online portfolio assessment, they can visit ReWELO website at www.rewelo.info. In addition, to be able to access the website it requires computer, laptop, notebook or smartphone connected to the internet. To visit the website, users (assessors, candidates and other visitors) can access it via browsers or search engines such as Mozilla Firefox, Google Chrome, Internet Explorer, Opera mini, and others.

\section{REFERENCES}

[1] Borg, W. R. \& Gall, M. D. (1989). Educational research an introduction. New York: Longman

[2] Bott, P. A. (1996). Testing and assessment in occupational and technical education. Boston: Allyn and Bacon

[3] Cropley, A.J. (1977). Lifelong Education: a psychological analysis Oxford: Pergamon.

[4] Department of Education and Culture. (2003). Undang-Undang RI Nomor 20, Tahun 2003, tentang Sistem Pendidikan Nasional.

[5] Department of Education and Culture. (2009). Peraturan Menteri Pendidikan Nasional RI No. 28 Tahun 2009 tentang Standar Kompetensi Kejuruan SMK/MAK

[6] Department of Education and Culture. (2013). Buku pintar Pengakuan Pengalaman Kerja dan Hasil Belajar (PPKHB).

[7] Department of Manpower and Transmigration. (2007). Keputusan Menteri Tenaga Kerja Transmigrasi dan Koperasi Republik Indonesia No. KEP.170/MEN/IV/2007 tentang SKKNI Sektor Listrik Sub Sektor Ketenagalistrikan.

[8] Directorate General of Higher Education, Ministry of National Education of the Republic of Indonesia (n.d.). Indonesian Qualification Framework Handbook (IQF) -1st EDITION. 
[9] Directorate General of Quality Improvement of Education and Education Personnel, Directorate General of Higher Education, Ministry of National Education of the Republic of Indonesia (2010). Rambu-Rambu Pengakuan Pengalaman Kerja dan Hasil Belajar (PPKHB) dalam penyelenggaraan Program Sarjana (S-1) Kependidikan bagi guru dalam jabatan Edisi 2010.

[10] Directorate General of Higher Education's Director of Learning and Student Affairs of Ministry of Education and Culture. (2010/2011). Sosialisasi Kerangka Kualifikasi Nasional Indonesia/ Indonesian Qualification Framework.

[11] Djojonegoro, W. (1998). Pengembangan sumber daya manusia melalui Sekolah Menengah Kejuruan (SMK). Jakarta: PT Jayakarta Agung Offset.

[12] Djoko Laras. (2013). Pengembangan model asesmen kompetensi keahlian pada sertifikasi eksternal kompetensi peserta didik Sekolah Menengah Kejuruan. Unpublished Doctorate Dissertation. Yogyakarta: Technology and Vocational Education Program, Postgraduate Program of Universitas Negeri Yogyakarta.

[13] Haryono, Kir. (1995). Pendidikan kejuruan dan filosofinya (sebagai system pendidikan bagi semua). Jurnal Cakrawala Pendidikan Edisi Khusus Dies, Mei 1995. Yogyakarta: IKIP Yogyakarta

[14] Johnson, R.L., Penny, J.A., Gordon, B. (2009). Assessing performance: designing, scoring, and validating performance tasks. New York: The Guilford Press.

[15] Kaprawi, N. Bte. (2011). Leveraging Accreditation of Prior Experiential Learning (APEL) for human capital development. Malaysia: University Tun Hussein Onn Malaysia.
[16] Lestari, I., \& Siswanto, B. (2015). Pengaruh Pengalaman Prakerin, Hasil Belajar Produktif dan Dukungan Sosial Terhadap Kesiapan Kerja Siswa SMK. Jurnal Pendidikan Vokasi, 5(2), 183-194. Retrieved from http://journal.uny.ac.id/index.php/jpv/article/view/6384

[17] Longworth, N. (2003). Lifelong learning in action transforming education in the 21st century. Londong: Kogan Page Limited.

[18] Mardapi, D. (2000). Konsep dasar assmen kinerja. Makalah Seminar Pengembangan Penilaian Kinerja, LPPM UNY.

[19] Miller, M.D. (1986). Principles and philosophy of vocational education. Boston: Allyn-Bacon.

[20] Republic of Indonesia (2008). Lampiran Kepmenakertrans RI No. 107/MEN/V/2008 tentang Penetapan SKKNI Sektor Listrik, Gas, dan Air. Jakarta: Ministry of Manpower and Transmigration

[21] Republic of Indonesia. (2013). Keputusan Menteri Pendidikan dan Kebudayaan No. 73 Year 2013 tentang Penerapan Kerangka Kualifikasi Nasional Indonesia Bidang Pendidikan Tinggi. Jakarta: Ministry of Education and Culture.

[22] Wellington, P. (2002). Authentic assessment applied to engineering and business undergraduate consulting team. Journal of Engineering of Education. Vol. 18. No.2, p. 168-179.

[23] Werquin, P. (2010) Terms, concept, and models for analysing the value of recognition programmes. Vienna Austria: Directorate for Education. 